Dział: Rolnictwo i Bioinżynieria

Copyright (CWydawnictwo Uniwersytetu Przyrodniczego w Poznaniu

PIOTR BARBAŚ ${ }^{1}$, BARBARA SAWICKA ${ }^{2}$

${ }^{1}$ Department of Potato Agronomy

Plant Breeding and Acclimatization Institute - National Research Institute, Jadwisin Research Center

${ }^{2}$ Department of Specific Plant Cultivation

University of Life Sciences in Lublin

\title{
IMPACT OF WEEDING METHODS ON THE CONTENT OF NITRATES IN POTATO TUBERS
}

\author{
ODDZIAEYWANIE METOD PIELEGNACJI \\ NA ZAWARTOŚĆ AZOTANÓW W BULWACH ZIEMNIAKA
}

\begin{abstract}
Summary
The test results were based on a field experiment conducted in 2007-2009 in pilot plant of Plant Breeding and Acclimatization Institute - National Research Institute in Jadwisin on lessive soil with granulometric composition of loamy sand. The experiment was carried out applying the method of drawn sub-blocks in the dependent arrangement, split-plot, in three replications. Row I factors were the cultivars 'Irga' and 'Fianna', and row II factors were weed control methods: 1) control object - without chemical protection, 2) extensive mechanical treatments (every 2 weeks), carried out after planting until rows reached closeness, 3) Sencor $70 \mathrm{WG}-1 \mathrm{~kg} \cdot \mathrm{ha}^{-1}$ of pre-emergence potato, 4) Sencor $70 \mathrm{WG}-1 \mathrm{~kg} \cdot \mathrm{ha}^{-1}+$ Titus $25 \mathrm{WG}-40 \mathrm{~g} \cdot \mathrm{ha}^{-1}+$ Trend $90 \mathrm{EC}-0.1 \%$ of pre-emergence potato, 5) Sencor $70 \mathrm{WG}-0.5 \mathrm{~kg} \cdot \mathrm{ha}^{-1}$ of post-emergence potato, 6) Sencor 70 WG $-0.3 \mathrm{~kg} \cdot \mathrm{ha}^{-1}+$ Titus $25 \mathrm{WG}-30 \mathrm{~g} \cdot \mathrm{ha}^{-1}+$ Trend $90 \mathrm{EC}-0.1 \%$ of post-emergence potato, 7) Sencor $70 \mathrm{WG}-0.3 \mathrm{~kg} \cdot \mathrm{ha}^{-1}+$ Fusilade Forte $150 \mathrm{EC}-2 \mathrm{dm} \cdot \mathrm{ha}^{-1}$ of post-emergence potato, 8) Sencor $70 \mathrm{WG}-0.3 \mathrm{~kg} \cdot \mathrm{ha}^{-1}+$ Apyros $75 \mathrm{WG}-26.5 \mathrm{~g} \cdot \mathrm{ha}^{-1}+$ Atpolan $80 \mathrm{SC}-1 \mathrm{dm} \cdot \mathrm{ha}^{-1}$ of post-emergence potato. Harvest was performed at the technical maturity of the potato. Nitrate markings were performed according to the colorimetric method. The value of the trait was to a large extent determined by genetic factors. A medium-early variety 'Irga' had a higher nitrate content compared to an average late variety 'Fianna'. Nitrate concentration in potato tubers was dependent on the applied weeding control methods used and atmospheric conditions in the research years. The tubers with the highest concentration of nitrates came from the facility where pre-emergence potato preparations Sencor $70 \mathrm{WG}+$ Titus $25 \mathrm{WG}+$ Trend $90 \mathrm{EC}$ were used.
\end{abstract}

Key words: potato, cultivar, weeding control methods, nitrates 
Barbaś, P., Sawicka, B. (2016). Impact of weeding methods on the content of nitrates in potato tubers. Nauka Przyr. Technol., 10, 4, \#49. DOI: http://dx.doi.org/10.17306/J.NPT.2016.4.49

\section{Introduction}

Potato is one of basic food plants whose tubers are consumed in Poland almost every day by majority of people. The direct proof of their nutritious value is the content and biological quality of the substances entering into their composition (starch, simple and reducing sugars, proteins, exogenous amino acids, lipids, mineral compounds, organic acids, vitamins, poliphenols etc.) (Leszczyński, 2012). Apart from the natural components of tubers having both nutritious and dietary values, there are also undesirable substances. They are natural components of the tubers or are produced either as a result of metabolic plant disturbances or get into it from the polluted environment. The undesirable substances comprise: glycoalkaloids, nitrates, nitrites, mycotoxins, pesticides remnants or heavy metals (Cieślik, 1995; Friedman, 2006; Janowiak et al., 2009; Knuthsen et al., 2009; Rytel, 2010; Tajner-Czopek et al., 2008; Zarzecka et al., 2015).

The content of nitrates oscillates at the level of 100-740 mg $\mathrm{NaNO}_{3}$ per $1 \mathrm{~kg}$, and on the average reaches $150-300 \mathrm{mg} \mathrm{NaNO} 3$ per $1 \mathrm{~kg}$. However, the values are significantly lower than it is in the case of other agricultural products such as: lettuce (1500-3000 $\left.\mathrm{mg} \cdot \mathrm{kg}^{-1}\right)$, cabbage $\left(1000-6500 \mathrm{mg} \cdot \mathrm{kg}^{-1}\right)$, parsley $\left(400-1100 \mathrm{mg} \cdot \mathrm{kg}^{-1}\right)$, sugar beet $(1400$ - $3200 \mathrm{mg} \cdot \mathrm{kg}^{-1}$ ) (Haddad et al. 2016; Janowiak et al., 2009; Marks, 2009; Mikos-Bielak et al., 1999; Murawa et al., 2008).

Nitrates (V) are relatively of low toxicity to people, however, they may be reduced to nitrites (III) in the organism. It is though commonly known that $3 / 4$ of food-products originating nitrates can be reduced to nitrites, which are undoubtedly more dangerous to the human and animal organisms than the nitrates themselves causing among others: oligocystosis, methaemoglobinaemia, vitamins A and B decomposition (Mikos-Bielak et al., 1999; Zgórska and Grudzińska, 2009). They are precursors of toxic N-nitrosine compounds occurring in food, e.g. 1,2-dimethylnitrosamine causing liver damages and inducing tumours. Nitrosamines, subjected to degradation to alkyl radicals, impair guanina in nucleic acids (Dżugan and Pasternakiewicz, 2007; Haddad et al., 2016; Kościańska and Rodecka-Gustaw, 2011). The compounds are consumed with food and at the dose as low as $10 \mathrm{mg} \cdot \mathrm{kg}^{-1}$ of body mass per day initiate the development of tumours in animals (Kardasz and Pawłowska, 2008; Valdés-Ramos and Benítez-Arciniega, 2007). Nitrates in potato tubers are situated in the peel and under it, and they are easily soluble in water. Thus peeling the skin, cutting, rinsing tubers in water, blanching and boiling reduce the content of the compounds (Mikos-Bielak et al., 1999; Zgórska and Grudzińska, 2009). Applying herbicides in potato cultivation will reduce the harmful weeds impact, yet it can simultaneously influence the changes in the chemical composition of the tubers, including nitrates (Wichrowska and Wojdyła, 2011). That is why the aim of the below study was an evaluation of the content of nitrates in potato tubers cultivated in conditions of varied weeding techniques.

\section{Material and methods}

The study results were based on the field experiment carried out in the period between 2007-2009, at the pilot plant of Plant Breeding and Acclimatization Institute - National Research Institute in Jadwisin. The soil was lessive of granulometric loamy sand composition, weak rye complex, medium phosphorus, potassium and magnesium-rich. 
Barbaś, P., Sawicka, B. (2016). Impact of weeding methods on the content of nitrates in potato tubers. Nauka Przyr. Technol., 10, 4, \#49. DOI: http://dx.doi.org/10.17306/J.NPT.2016.4.49

The experiment was carried out applying the method of drawn sub-blocks in the dependent arrangement, split-plot, in three replications (Trętowski and Wójcik, 1991). Row I factors were the cultivars 'Irga' and 'Fianna', and row II factors were weed control methods: 1) control object - without chemical protection, 2) extensive mechanical treatments (every 2 weeks), carried out after planting till rows reached closeness, 3) Sencor $70 \mathrm{WG}-1 \mathrm{~kg} \cdot \mathrm{ha}^{-1}$ of pre-emergence potato, 4) Sencor $70 \mathrm{WG}-1 \mathrm{~kg} \cdot \mathrm{ha}^{-1}+$ Titus $25 \mathrm{WG}-40 \mathrm{~g} \cdot \mathrm{ha}^{-1}+$ Trend $90 \mathrm{EC}-0.1 \%$ of pre-emergence potato, 5) Sencor 70 $\mathrm{WG}-0.5 \mathrm{~kg} \cdot \mathrm{ha}^{-1}$ of post-emergence potato, 6) Sencor $70 \mathrm{WG}-0.3 \mathrm{~kg} \cdot \mathrm{ha}^{-1}+$ Titus 25 $\mathrm{WG}-30 \mathrm{~g} \cdot \mathrm{ha}^{-1}+$ Trend $90 \mathrm{EC}-0.1 \%$ of post-emergence potato, 7) Sencor $70 \mathrm{WG}-$ $0.3 \mathrm{~kg} \cdot \mathrm{ha}^{-1}+$ Fusilade Forte $150 \mathrm{EC}-2 \mathrm{dm} \cdot \mathrm{ha}^{-1}$ of post-emergence potato, 8) Sencor 70 $\mathrm{WG}-0.3 \mathrm{~kg} \cdot \mathrm{ha}^{-1}+$ Apyros $75 \mathrm{WG}-26.5 \mathrm{~g} \cdot \mathrm{ha}^{-1}+$ Atpolan $80 \mathrm{SC}-1 \mathrm{dm} \cdot \mathrm{ha}^{-1}$ of post-emergence potato. $400 \mathrm{dm} \cdot \mathrm{ha}^{-1}$ water was used for spraying the plants with herbicides. Metribuzin was applied in Sencor 70 WG preparation form, sulfosulfuron - Apyros 75 WG, rimsulfuron - herbicide Titus $25 \mathrm{WG}$, and fluazyfop - Fusilade Forte 150 EC. The potato forecrop was winter wheat, and after it's harvested white mustard was sown as an intercrop for ploughing in. Nitrogen fertilization was carried out at the quantity of $50 \mathrm{~kg}$ $\mathrm{N}$ per 1 ha, skimming and sowing of white mustard at $20 \mathrm{~kg} \cdot \mathrm{ha}-1$ were conducted after the wheat harvest.

Mineral phosphorus-potassium fertilization at the dose of $39.3 \mathrm{~kg} \mathrm{P}$ per 1 ha and $116.2 \mathrm{~kg} \mathrm{~K}$ per 1 ha was applied and covered by autumn ploughing every autumn prior to the planting. Nitrogen fertilizers were sown in spring at $100 \mathrm{~kg} \mathrm{~N}$ per 1 ha, and mixed with soil using the cultivation unit (cultivator + string roller). Potato tubers were planted manually, in the third decade of April at $75 \times 33 \mathrm{~cm}$ spacing. Reproduction material was of C/A class. Herbicide measures were conducted manually with an application of a knapsack sprayer. Protection of potato against diseases and pests was carried out in agreement with Institute of Plant Protection - National Research Institute recommendations. To protect potatoes against alternariose and potato blight the following fungicides were applied: Tattoo C $750 \mathrm{SC}$ at the dose of $2.5 \mathrm{dm} \cdot \mathrm{ha}^{-1}$, Altima $500 \mathrm{SC}-0.4 \mathrm{dm} \cdot \mathrm{ha}^{-1}$, Pyton $60 \mathrm{WG}-1.25 \mathrm{~kg} \cdot \mathrm{ha}^{-1}$, Ridomil Gold MZ $60 \mathrm{WG}-2.5 \mathrm{~kg} \cdot \mathrm{ha}^{-1}$. To reduce the Colorado beetle occurrence the following pesticides were used: Actara $25 \mathrm{WG}$ at the dose of $0.4 \mathrm{~kg} \cdot \mathrm{ha}^{-1}$, Proagro $100 \mathrm{SL}-0.25 \mathrm{dm} \cdot \mathrm{ha}^{-1}$, Calypso $480 \mathrm{SC}-0.75 \mathrm{dm} \cdot \mathrm{ha}^{-1}$ and Mospilan $20 \mathrm{SP}-0.05 \mathrm{~kg} \cdot \mathrm{ha}^{-1}$. The application was carried out in agreement with Institute of Plant Protection - National Research Institute recommendations. Potato elevator digger was used to collect the tubers in the third decade of September. Representative tuber samples were collected from each field plot for chemical analyses. The marking of nitrates in tubers' fresh mass was conducted by help of the colorimetric method basing on Griess' reaction using a mixture of zinc and manganese with a reduction of nitrates to nitrites taking place (Fortuna, 2003), in the Chemical Laboratory of PBAI - NRI in Jadwisin.

Statistical package SAS v.9.2 was applied to carry out statistical analyses. They were based on triple factor models (years $\times$ cultivars $\times$ methods) of the analysis of variance (ANOVA), as well as t-Tukey's multiple tests (or confidence intervals), after the significance level 0.05 had been accepted. The significance of the variability sources was verified by F-Snedecor's test. The computation of the significance of differences between the compared means was conducted by means of Tukey's multiple intervals. Tukey's multiple comparisons tests facilitated detailed comparative analyses of means, 
Barbaś, P., Sawicka, B. (2016). Impact of weeding methods on the content of nitrates in potato tubers. Nauka Przyr. Technol., 10, 4, \#49. DOI: http://dx.doi.org/10.17306/J.NPT.2016.4.49

isolating statistically homogeneous groups of means, and defining the so-called least significant differences of means, which in Tukey's tests are marked by HSD (Tukey's Honest Significant Difference). The results of the infestation evaluation, connected with: the general number of weeds before rows' closeness was completed, number of weeds before potato harvesting, their fresh and dry matter, as well as nitrate content, were subjected to the multiple regression analysis.

The variability of the analysed results was characterized by means of: arithmetic mean, standard deviation and variability coefficient $V$ calculated according to the formula: $V=(S / \bar{x}) \cdot 100$, where $S$ - standard deviation, $\bar{x}$ - arithmetic mean (Koronacki and Mielniczuk, 2006).

The conditions of vegetation in 2007-2009 were of varied air temperatures and precipitation (Fig. 1). 2007 can be described as fairly dry, 2008 - as dry, and 2009 - as the year with the most favourable moisture-thermal conditions for potato cultivation.

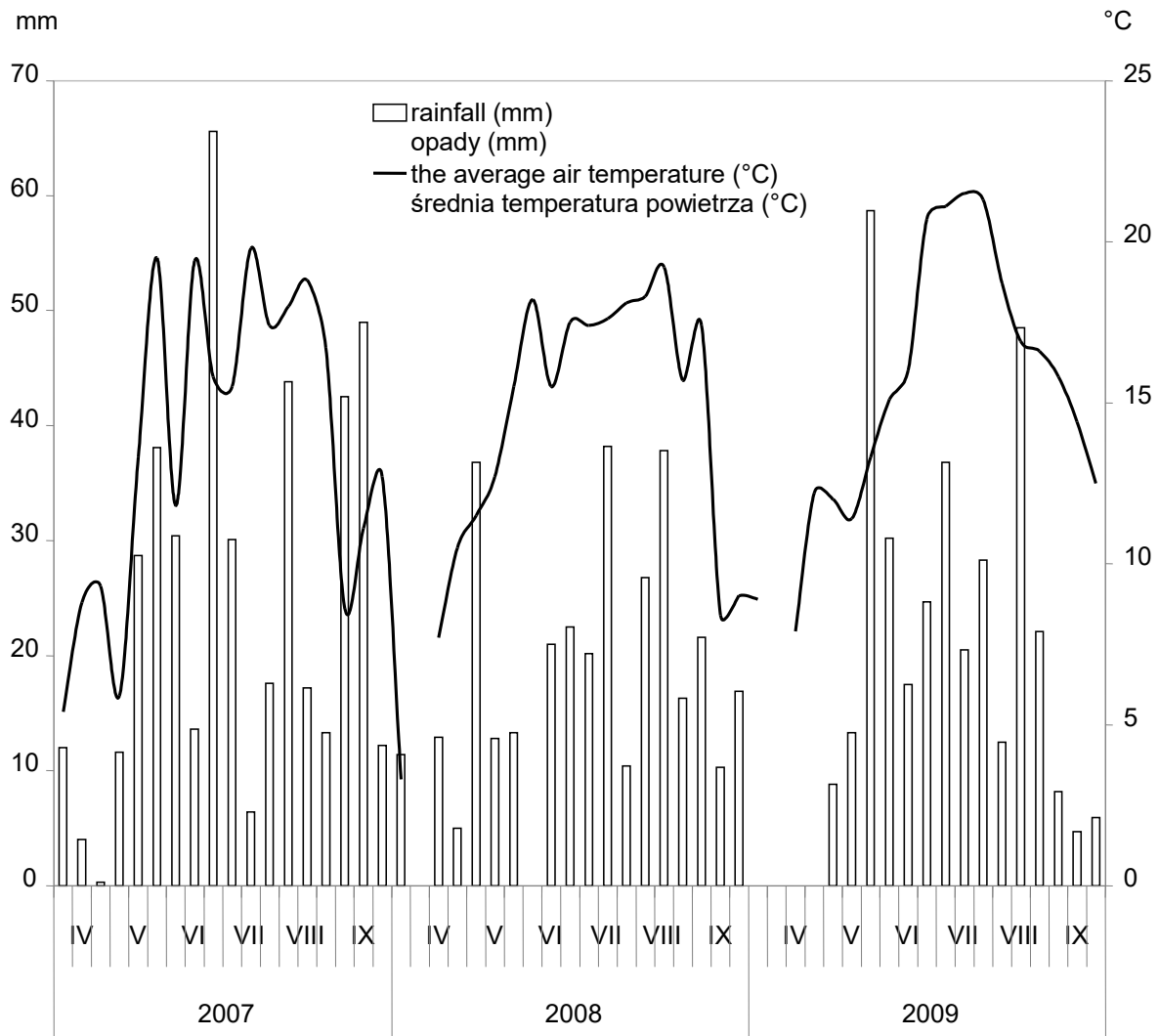

Fig. 1. Rainfall and air temperature during the potato growing season according to the weather station PBAI - NRI in Jadwisin (2007-2009) against the multiannual means

Rys. 1. Opady i temperatura powietrza w okresie wegetacji ziemniaka według stacji meteorologicznej IHAR - PIB w Jadwisinie (lata 2007-2009) na tle średnich wieloletnich 
Barbaś, P., Sawicka, B. (2016). Impact of weeding methods on the content of nitrates in potato tubers. Nauka Przyr. Technol., 10, 4, \#49. DOI: http://dx.doi.org/10.17306/J.NPT.2016.4.49

Mean temperature of April-September period of 2007 reached $13.7^{\circ} \mathrm{C}$ and was lower than the multi-year mean for the period by $0.6^{\circ} \mathrm{C}$. The precipitation sum for the period was $436.4 \mathrm{~mm}$, which meant $165.3 \%$ of the multi-year norm. The weather course for the 2008 vegetation was non-typical. The precipitation sum for May and August exceeded the multi-year norm, and in the other months a meaningful water deficit was observed, and both June and July were dry. Mean air temperature of April-September period was $14.2^{\circ} \mathrm{C}$ and was lower than the multi-year mean by $0.3^{\circ} \mathrm{C}$. The meteorological conditions for the 2009 vegetation period were varied but their common feature was a period of drought which occurred at the beginning of the potato vegetation. Mean temperature of the April-September period was $15.3^{\circ} \mathrm{C}$, which was a deviation from the multi-year mean by $0.1{ }^{\circ} \mathrm{C}$, whereas the precipitation sum of the period was at the level of 359.5 $\mathrm{mm}$ and was lower than the multi-year mean by $4.3 \mathrm{~mm}$ (Fig. 1).

\section{Results}

The content of nitrates in potato tubers depended upon all the studied factors of the experiment. The medium early cultivar 'Irga' showed a higher content of the compound compared to the medium late cultivar 'Fianna' (Table 1). Herbicide-asissted weed control, accompanying the carried out experiments, significantly influenced an accumulation of nitrates in the tubers. An increase of this form of nitrogen in tubers, compared to mechanical application control, was observed in all objects except from the combination with the post-emergence application of Sencor $70 \mathrm{WG}+$ Titus $25 \mathrm{WG}+$ Trend $90 \mathrm{EC}$ herbicide mixture. The highest nitrate content was observed in tubers coming from the object where in the pre-emergence potato period the following preparations were used: Sencor $70 \mathrm{WG}-1 \mathrm{~kg} \cdot \mathrm{ha}^{-1}+$ Titus $25 \mathrm{WG}-40 \mathrm{~g} \cdot \mathrm{ha}^{-1}+$ Trend $90 \mathrm{EC}-0.1 \%$. The lowest concentration of the nitrogen form in tubers was recorded in combinations with: Sencor $70 \mathrm{WG}-0.3 \mathrm{~kg} \cdot \mathrm{ha}^{-1}+$ Titus $25 \mathrm{WG}-30 \mathrm{~g} \cdot \mathrm{ha}^{-1}+$ Trend $90 \mathrm{EC}-0.1 \%$, applied after the emergence (Table 1).

The atmospheric conditions at the time of the experiment significantly influenced the content of nitrates in tubers of the edible potato (Table 1). The lowest concentration of the component was observed in 2008 which was characterized by a non-typical weather course. The May-August period precipitation sum exceeded the multi-year norm, whereas June and July were dry. The year had a lower, compared to the multi-year, air temperature at the period of accumulation of nutritive compounds. Then, the content of nitrates in tubers, in 2007 and 2009, i.e. both in a fairly dry year and the one most favourable in terms of humidity and temperature conditions, turned out to be homologous in respect of the feature. The examined cultivars reacted in a similar way to the edaphic-climatic conditions at the time of the experiment (Table 1).

An influence of the control method on the nitrate content depended on the atmospheric conditions at the time of the experiment. Significant differences in the nitrate content in potato tubers, at the study time, were proved for the following methods: 4,5 , 6 and 7 (Fig. 2). The highest content of the nitrogen form in tubers was reported in combination 4, with the weed control method using Sencor $70 \mathrm{WG}+$ Titus $25 \mathrm{WG}+$ Trend $90 \mathrm{EC}$ at the pre-emergence time or in combination 8, with Sencor $70 \mathrm{WG}+$ Apyros $75 \mathrm{WG}+$ Atpolan $80 \mathrm{SC}$ herbicide mixture, applied at the post-emergence time, 
Barbaś, P., Sawicka, B. (2016). Impact of weeding methods on the content of nitrates in potato tubers. Nauka Przyr. Technol., 10, 4, \#49. DOI: http://dx.doi.org/10.17306/J.NPT.2016.4.49

Table 1. Nitrate content in the fresh potato tubers matter depending on weed control systems, cultivars and years $\left(\mathrm{mg} \cdot \mathrm{kg}^{-1}\right)$

Tabela 1. Zawartość azotanów w świeżej masie bulw ziemniaka w zależności od sposobów pielęgnowania, odmian i lat $\left(\mathrm{mg} \cdot \mathrm{kg}^{-1}\right)$

\begin{tabular}{|c|c|c|c|c|c|c|c|c|c|}
\hline \multirow{2}{*}{$\begin{array}{l}\text { Cultivar } \\
\text { Odmiana }\end{array}$} & \multirow{2}{*}{$\begin{array}{l}\text { Year } \\
\text { Rok }\end{array}$} & \multicolumn{8}{|c|}{ Weed control systems* - Sposoby pielęgnacji* } \\
\hline & & 1 & 2 & 3 & 4 & 5 & 6 & 7 & 8 \\
\hline \multirow[t]{4}{*}{ 'Irga' } & 2007 & 36.1 & 52.6 & 77.8 & 121.4 & 119.4 & 98.1 & 129.4 & 139.3 \\
\hline & 2008 & 35.0 & 63.2 & 78.5 & 123.2 & 112.3 & 94.4 & 132.5 & 138.7 \\
\hline & 2009 & 35.8 & 62.8 & 78.3 & 121.7 & 115.2 & 93.7 & 132.6 & 139.8 \\
\hline & $\begin{array}{l}\text { Mean } \\
\text { Średnio }\end{array}$ & 35.6 & 59.5 & 78.2 & 122.1 & 115.6 & 95.4 & 131.5 & 139.2 \\
\hline \multirow[t]{4}{*}{ 'Fianna' } & 2007 & 20.9 & 49.6 & 51.3 & 96.3 & 32.6 & 15.0 & 43.8 & 47.6 \\
\hline & 2008 & 14.6 & 55.8 & 50.0 & 95.4 & 33.4 & 15.5 & 31.4 & 45.7 \\
\hline & 2009 & 15.5 & 55.9 & 48.9 & 98.2 & 33.0 & 15.2 & 31.4 & 44.8 \\
\hline & $\begin{array}{l}\text { Mean } \\
\text { Średnio }\end{array}$ & 17.0 & 53.7 & 50.0 & 96.6 & 33.0 & 15.2 & 35.5 & 46.0 \\
\hline \multirow{3}{*}{$\begin{array}{l}\text { Mean } \\
\text { Średnio }\end{array}$} & 2007 & 28.5 & 51.1 & 64.5 & 108.8 & 76.0 & 56.5 & 56.5 & 93.4 \\
\hline & 2008 & 24.8 & 59.5 & 64.2 & 109.3 & 72.8 & 54.9 & 54.9 & 92.2 \\
\hline & 2009 & 25.6 & 59.3 & 63.6 & 109.9 & 74.1 & 54.4 & 54.4 & 92.2 \\
\hline \multicolumn{2}{|c|}{ Mean - Średnio } & 26.3 & 56.6 & 64.1 & 109.3 & 74.3 & 55.3 & 83.5 & 92.6 \\
\hline
\end{tabular}

$\mathrm{LSD}_{\alpha=0.05}$ for cultivar $-0.8 ; \mathrm{LSD}_{\alpha=0.05}$ for year $-1.1 ; \mathrm{LSD}_{\alpha=0.05}$ for weed control system $-2.4 ; \mathrm{LSD}_{\alpha=0.05}$ for cultivar $\times$ year - n.i.; $\operatorname{LSD}_{\alpha=0.05}$ for cultivar $\times$ weed control system - n.i.

*Weed control systems: 1) control object - without chemical protection, 2) extensive mechanical treatments (every 2 weeks), after planting till rows closeness, 3) Sencor $70 \mathrm{WG}-1 \mathrm{~kg} \cdot \mathrm{ha}^{-1}$ of pre-emergence potato, 4) Sencor $70 \mathrm{WG}-1 \mathrm{~kg} \cdot \mathrm{ha}^{-1}+$ Titus $25 \mathrm{WG}-40 \mathrm{~g} \cdot \mathrm{ha}^{-1}+$ Trend $90 \mathrm{EC}-0.1 \%$ of pre-emergence potato, 5) Sencor $70 \mathrm{WG}-0.5 \mathrm{~kg} \cdot \mathrm{ha}^{-1}$ of post-emergence potato, 6) Sencor $70 \mathrm{WG}-0.3 \mathrm{~kg} \cdot \mathrm{ha}^{-1}+\mathrm{Titus}^{25}$ $\mathrm{WG}-30 \mathrm{~g} \cdot \mathrm{ha}^{-1}+$ Trend $90 \mathrm{EC}-0.1 \%$ of post-emergence potato, 7) Sencor $70 \mathrm{WG}-0.3 \mathrm{~kg} \cdot \mathrm{ha}^{-1}+$ Fusilade $^{-1}$ Forte $150 \mathrm{EC}-2 \mathrm{dm} \cdot \mathrm{ha}^{-1}$ of post-emergence potato, 8) Sencor $70 \mathrm{WG}-0.3 \mathrm{~kg} \cdot \mathrm{ha}^{-1}+$ Apyros $75 \mathrm{WG}-26.5$ $\mathrm{g} \cdot \mathrm{ha}^{-1}+$ Atpolan $80 \mathrm{SC}-1 \mathrm{dm} \cdot \mathrm{ha}^{-1}$ of post-emergence potato.

$\mathrm{NIR}_{\alpha=0,05}$ dla odmiany - 0,8; $\mathrm{NIR}_{\alpha=0,05}$ dla roku - 1,1; $\mathrm{NIR}_{\alpha=0,05}$ dla sposobu pielęgnacji $-2,4 ; \mathrm{NIR}_{\alpha=0,05}$ dla odmiany $\times$ rok - n.i; $\mathrm{NIR}_{\alpha=0,05}$ dla odmiany $\times$ sposób pielęgnacji - n.i.

*Sposoby pielęgnacji: 1) obiekt kontrolny - bez chemicznej ochrony, 2) ekstensywne zabiegi mechaniczne (co 2 tygodnie) od posadzenia aż do zwarcia rzędów, 3) Sencor $70 \mathrm{WG}-1 \mathrm{~kg} \cdot \mathrm{ha}^{-1} \mathrm{przed}$ wschodami ziemniaka, 4) Sencor $70 \mathrm{WG}-1 \mathrm{~kg} \cdot \mathrm{ha}^{-1}+$ Titus $25 \mathrm{WG}-40 \mathrm{~g} \cdot \mathrm{ha}^{-1}+$ Trend $90 \mathrm{EC}-0,1 \%$ przed wschodami ziemniaka, 5) Sencor $70 \mathrm{WG}-0,5 \mathrm{~kg} \cdot \mathrm{ha}^{-1}$ po wschodach ziemniaka, 6) Sencor $70 \mathrm{WG}-0,3 \mathrm{~kg} \cdot \mathrm{ha}^{-1}+$ Titus $25 \mathrm{WG}-30 \mathrm{~g} \cdot \mathrm{ha}^{-1}+$ Trend $90 \mathrm{EC}-0,1 \%$ po wschodach ziemniaka, 7) Sencor $70 \mathrm{WG}-0,3 \mathrm{~kg} \cdot \mathrm{ha}^{-1}$ + Fusilade Forte $150 \mathrm{EC}-2 \mathrm{dm} \cdot \mathrm{ha}^{-1}$ po wschodach ziemniaka, 8) Sencor $70 \mathrm{WG}-0,3 \mathrm{~kg} \cdot \mathrm{ha}^{-1}+\mathrm{Apyros}^{75}$ $\mathrm{WG}-26,5 \mathrm{~g} \cdot \mathrm{ha}^{-1}+$ Atpolan $80 \mathrm{SC}-1 \mathrm{dm} \cdot \mathrm{ha}^{-1}$ po wschodach ziemniaka.

at optimal, in respect of 2009 humidity conditions, but, on the other hand, characterized by drought at the beginning of the potato vegetation period. Significant differences in the content of nitrates between the years were also found in the combinations with the method applying: Sencor $70 \mathrm{WG}+$ Fusilade Forte $150 \mathrm{EC}$ and Sencor $70 \mathrm{WG}+$ Titus 
Barbaś, P., Sawicka, B. (2016). Impact of weeding methods on the content of nitrates in potato tubers. Nauka Przyr. Technol., 10, 4, \#49. DOI: http://dx.doi.org/10.17306/J.NPT.2016.4.49

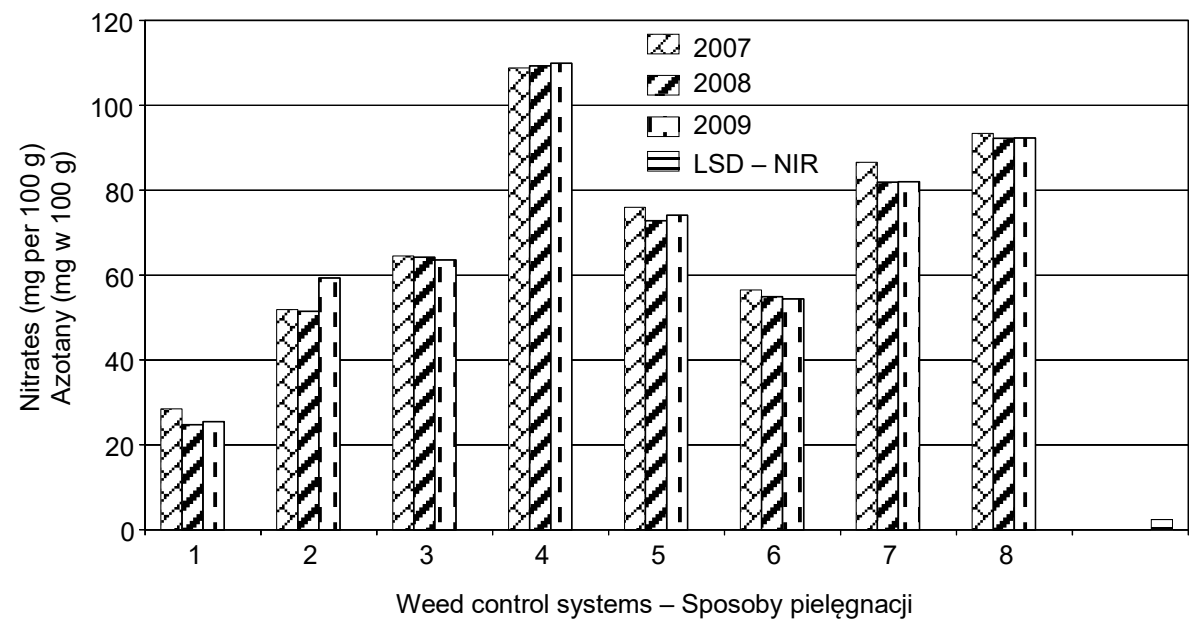

Fig. 2. Effect of weed control systems and years of research on the nitrate content in tubers Rys. 2. Wpływ sposobów pielęgnacji i lat badań na zawartość azotanów w bulwach

$25 \mathrm{WG}+$ Trend $90 \mathrm{EC}$ - used at the post-emergence period. Their highest concentration was reported in 2007 (dry year), whereas in the other years it was homogeneous owing to the content of this form of nitrogen. The methods with Sencor application in combination with other preparations, used either at the pre- or post-emergence time, turned out to be the most efficient ones, and at the same time homologous as far as the value of the feature for the 2008 season with its most favourable conditions for the crop storage. A significant impact of the weed control method on the number of weeds, their fresh and air-dry mass made the authors to analyse the dependencies between weed infestation and nitrates concentration in potato tubers. The obtained results indicate a significant, negative influence of the successive infestation elements on the content of nitrates (Table 2). It was most effectively reduced by the number of weeds after the rows had been closed, as well as fresh weed mass before potato's harvest. Negative dependencies between the weed infestation and the content of nitrates were reported in all the objects both with mechanical and chemical control method (Table 2).

Moreover, the dependencies gathered in Table 2 indicate that, independently of the applied control method and the date of the infestation evaluation, air-dry and fresh weed mass was positively correlated with the number of monocotyledonous and dicotyledonous weeds occurring on the area of potato plantations, which resulted from the interior (inter)correlation.

The number of weeds on $1 \mathrm{~m}^{2}$ before row closing, and before harvest, as well as fresh and dry weed mass, proved to be negatively correlated with the content of nitrates in potato tubers. It made the authors carry out the analysis of the multinomial regression. The obtained data indicate a significantly negative impact of the successive weed infestation components on the content of nitrates in potato tubers (Table 2). The content was most meaningfully lowered by the fresh weed mass prior to potato harvest. The dependencies were considered in respect of the standard deviation of independent variables of the arithmetic mean (Table 3). The content of nitrates in tubers proved the highest 
Barbaś, P., Sawicka, B. (2016). Impact of weeding methods on the content of nitrates in potato tubers. Nauka Przyr. Technol., 10, 4, \#49. DOI: http://dx.doi.org/10.17306/J.NPT.2016.4.49

Table 2. Coefficients of Pearson's simple correlation between crop weeds and nitrate content in potato tubers

Tabela 2. Współczynniki korelacji prostej Pearsona pomiędzy zachwaszczeniem łanu a zawartością azotanów w bulwach ziemniaka

\begin{tabular}{|c|c|c|c|c|c|}
\hline $\begin{array}{l}\text { Coefficient } \\
\text { Współczynnik }\end{array}$ & $y$ & $x_{1}$ & $x_{2}$ & $x_{3}$ & $x_{4}$ \\
\hline 1 & 2 & 3 & 4 & 5 & 6 \\
\hline \multicolumn{6}{|c|}{$\begin{array}{l}\text { Control object - without chemical protection } \\
\text { Obiekt kontrolny - bez chemicznej ochrony }\end{array}$} \\
\hline$y$ & 1.00 & & & & \\
\hline$x_{1}$ & $-0.351 * *$ & 1.00 & & & \\
\hline$x_{2}$ & $-0.274 *$ & $0.830^{* *}$ & 1.00 & & \\
\hline$x_{3}$ & $-0.338^{* *}$ & $0.666^{* *}$ & $0.578 * *$ & 1.00 & \\
\hline$x_{4}$ & $-0.279 *$ & $0.574^{* *}$ & $0.494 * *$ & $0.902 * *$ & 1.00 \\
\hline \multicolumn{6}{|c|}{$\begin{array}{l}\text { Mechanical weed control } \\
\text { Pielęgnacja mechaniczna }\end{array}$} \\
\hline$y$ & 1.00 & & & & \\
\hline$x_{1}$ & $-0.360 * *$ & 1.00 & & & \\
\hline$x_{2}$ & $-0.275^{*}$ & $0.832 * *$ & 1.00 & & \\
\hline$x_{3}$ & $-0.334^{* *}$ & $0.666^{* *}$ & $0.579 * *$ & 1.00 & \\
\hline$x_{4}$ & $-0.278^{*}$ & $0.574^{* *}$ & $0.494^{* *}$ & $0.903 * *$ & 1.00 \\
\hline \multicolumn{6}{|c|}{$\begin{array}{l}\text { Sencor } 70 \mathrm{WG}-1 \mathrm{~kg} \cdot \mathrm{ha}^{-1} \text { of pre-emergence potato } \\
\text { Sencor } 70 \mathrm{WG}-1 \mathrm{~kg} \cdot \mathrm{ha}^{-1} \text { przed wschodami ziemniaka }\end{array}$} \\
\hline$y$ & 1.00 & & & & \\
\hline$x_{1}$ & $-0.365^{* *}$ & 1.00 & & & \\
\hline$x_{2}$ & $-0.278^{*}$ & $0.833^{* *}$ & 1.00 & & \\
\hline$x_{3}$ & $-0.332 * *$ & $0.660^{* *}$ & $0.574 * *$ & 1.00 & \\
\hline$x_{4}$ & $-0.274 *$ & $0.565^{* *}$ & $0.486^{* *}$ & $0.903 * *$ & 1.00 \\
\hline \multicolumn{6}{|c|}{$\begin{array}{l}\text { Sencor } 70 \mathrm{WG}-1 \mathrm{~kg} \cdot \mathrm{ha}^{-1}+\text { Titus } 25 \mathrm{WG}-40 \mathrm{~g} \cdot \mathrm{ha}^{-1}+\text { Trend } 90 \mathrm{EC}-0.1 \% \text { of pre-emergence potato } \\
\text { Sencor } 70 \mathrm{WG}-1 \mathrm{~kg} \cdot \mathrm{ha}^{-1}+\text { Titus } 25 \mathrm{WG}-40 \mathrm{~g} \cdot \mathrm{ha}^{-1}+\text { Trend } 90 \mathrm{EC}-0.1 \% \text { przed wschodami ziemniaka }\end{array}$} \\
\hline$y$ & 1.00 & & & & \\
\hline$x_{1}$ & $-0.364 * *$ & 1.00 & & & \\
\hline$x_{2}$ & $-0.273 *$ & $0.831^{* *}$ & 1.00 & & \\
\hline$x_{3}$ & $-0.335^{* *}$ & $0.659^{* *}$ & $0.570^{* *}$ & 1.00 & \\
\hline$x_{4}$ & $-0.278 *$ & $0.564^{* *}$ & $0.482 * *$ & $0.903 * *$ & 1.00 \\
\hline
\end{tabular}


Barbaś, P., Sawicka, B. (2016). Impact of weeding methods on the content of nitrates in potato tubers. Nauka Przyr. Technol., 10, 4, \#49. DOI: http://dx.doi.org/10.17306/J.NPT.2016.4.49

Table 2 - cont. / Tabela 2 - cd.

\begin{tabular}{|c|c|c|c|c|c|}
\hline 1 & 2 & 3 & 4 & 5 & 6 \\
\hline \multicolumn{7}{|c|}{ Sencor 70 WG $-0.5 \mathrm{~kg} \cdot \mathrm{ha}^{-1}$ of post-emergence potato } \\
Sencor 70 WG $-0,5 \mathrm{~kg} \cdot \mathrm{ha}^{-1}$ po wschodach ziemniaka \\
\hline$y$ & 1.00 & & & & \\
$x_{1}$ & $-0.354^{* *}$ & 1.00 & & & \\
$x_{2}$ & $-0.264^{*}$ & $0.832^{* *}$ & 1.00 & & \\
$x_{3}$ & $-0.323^{* *}$ & $0.661^{* *}$ & $0.572^{* *}$ & 1.00 & 1.00 \\
$x_{4}$ & $-0.267^{*}$ & $0.568^{* *}$ & $0.485^{* *}$ & $0.904^{* *}$ & \\
\hline
\end{tabular}

Sencor $70 \mathrm{WG}-0.3 \mathrm{~kg} \cdot \mathrm{ha}^{-1}+$ Titus $25 \mathrm{WG}-30 \mathrm{~g} \cdot \mathrm{ha}^{-1}+$ Trend $90 \mathrm{EC}-0.1 \%$ of post-emergence potato Sencor $70 \mathrm{WG}-0,3 \mathrm{~kg} \cdot \mathrm{ha}^{-1}+$ Titus $25 \mathrm{WG}-30 \mathrm{~g} \cdot \mathrm{ha}^{-1}+$ Trend $90 \mathrm{EC}-0,1 \%$ po wschodach ziemniaka

\begin{tabular}{|c|c|c|c|c|c|}
\hline$y$ & 1.00 & & & & \\
\hline$x_{1}$ & $-0.353 * *$ & 1.00 & & & \\
\hline$x_{2}$ & $-0.269 *$ & $0.833^{* *}$ & 1.00 & & \\
\hline$x_{3}$ & $-0.309^{*}$ & $0.654 * *$ & $0.565^{* *}$ & 1.00 & \\
\hline$x_{4}$ & $-0.256^{*}$ & $0.561^{* *}$ & $0.480^{* *}$ & $0.905^{* *}$ & 1.00 \\
\hline \multicolumn{6}{|c|}{$\begin{array}{l}\text { Sencor } 70 \mathrm{WG}-0.3 \mathrm{~kg} \cdot \mathrm{ha}^{-1}+\text { Fusilade Forte } 150 \mathrm{EC}-2 \mathrm{dm} \cdot \mathrm{ha}^{-1} \text { of post-emergence potato } \\
\text { Sencor } 70 \mathrm{WG}-0,3 \mathrm{~kg} \cdot \mathrm{ha}^{-1}+\text { Fusilade Forte } 150 \mathrm{EC}-2 \mathrm{dm} \cdot \mathrm{ha}^{-1} \text { po wschodach ziemniaka }\end{array}$} \\
\hline$y$ & 1.00 & & & & \\
\hline$x_{1}$ & $-0.347 * *$ & 1.00 & & & \\
\hline$x_{2}$ & $-0.267 *$ & $0.834 * *$ & 1.00 & & \\
\hline$x_{3}$ & $-0.299 *$ & $0.656^{* *}$ & $0.566^{* *}$ & 1.00 & \\
\hline$x_{4}$ & $-0.247^{*}$ & $0.563^{* *}$ & $0.481^{* *}$ & $0.905^{* *}$ & 1.00 \\
\hline \multicolumn{6}{|c|}{$\begin{array}{l}\text { Sencor } 70 \mathrm{WG}-0.3 \mathrm{~kg} \cdot \mathrm{ha}^{-1}+\text { Apyros } 75 \mathrm{WG}-26.5 \mathrm{~g} \cdot \mathrm{ha}^{-1}+\text { Atpolan } 80 \mathrm{SC}-1 \mathrm{dm} \cdot \mathrm{h}^{-1} \text { of post-emergence potato } \\
\text { Sencor } 70 \mathrm{WG}-0,3 \mathrm{~kg} \cdot \mathrm{ha}^{-1}+\text { Apyros } 75 \mathrm{WG}-26,5 \mathrm{~g} \cdot \mathrm{ha}^{-1}+\text { Atpolan } 80 \mathrm{SC}-1 \mathrm{dm} \cdot \mathrm{ha}^{-1} \text { po wschodach ziemniaka }\end{array}$} \\
\hline$y$ & 1.00 & & & & \\
\hline$x_{1}$ & $-0.345^{* *}$ & 1.00 & & & \\
\hline$x_{2}$ & $-0.256^{*}$ & $0.835^{* *}$ & 1.00 & & \\
\hline$x_{3}$ & $-0.293^{*}$ & $0.657^{* *}$ & $0.566^{* *}$ & 1.00 & \\
\hline$x_{4}$ & $-0.241^{*}$ & $0.565^{* *}$ & $0.482^{* *}$ & $0.906^{* *}$ & 1.00 \\
\hline
\end{tabular}

$y_{1}$ - nitrate content $\left(\mathrm{mg} \cdot \mathrm{kg}^{-1}\right), x_{1}$ - number of weeds per $1 \mathrm{~m}^{2}$ before rows closeness, $x_{2}$ - number of weeds per $1 \mathrm{~m}^{2}$ before tubers harvest, $x_{3}$ - fresh matter of weeds before tubers harvest $\left(\mathrm{g} \cdot \mathrm{m}^{-2}\right), x_{4}$ - air-dry matter of weeds before tubers harvest $\left(\mathrm{g} \cdot \mathrm{m}^{-2}\right)$.

$*$ - significant at the level of $0.05, * *$ - significant at the level of 0.01 .

$y_{1}$ - zawartość azotanów $\left(\mathrm{mg} \cdot \mathrm{kg}^{-1}\right), x_{1}$ - liczba chwastów na $1 \mathrm{~m}^{2}$ przed zwarciem rzędów, $x_{2}$ - liczba chwastów na $1 \mathrm{~m}^{2}$ przed zbiorem bulw, $x_{3}$ - świeża masa chwastów przed zbiorem bulw $\left(\mathrm{g} \cdot \mathrm{m}^{-2}\right), x_{4}$ - powietrznie sucha masa chwastów przed zbiorem bulw $\left(\mathrm{g} \cdot \mathrm{m}^{-2}\right)$.

$*$ - istotne przy poziomie $0,05, * *-$ istotne przy poziomie 0,01 . 
Barbaś, P., Sawicka, B. (2016). Impact of weeding methods on the content of nitrates in potato tubers. Nauka Przyr. Technol., 10, 4, \#49. DOI: http://dx.doi.org/10.17306/J.NPT.2016.4.49

Table 3. Statistical characteristics of dependent and independent variables

Tabela 3. Charakterystyka statystyczna zmiennych zależnych i niezależnych

\begin{tabular}{|c|c|c|c|}
\hline $\begin{array}{l}\text { Weed control system* } \\
\text { Sposób pielęgnacji* }\end{array}$ & $\begin{array}{l}\text { Arithmetic mean } \\
\text { Srednia arytmetyczna }\end{array}$ & $\begin{array}{l}\text { Standard deviation } \\
\text { Odchylenie standardowe }\end{array}$ & $\begin{array}{c}\text { Variability coefficient } \\
\text { Współczynnik zmienności }\end{array}$ \\
\hline 1 & 2 & 3 & 4 \\
\hline \multicolumn{4}{|c|}{$\begin{array}{c}\text { Nitrate content }\left(\mathrm{mg} \cdot \mathrm{kg}^{-1}\right) \\
\text { Zawartość azotanów }\left(\mathrm{mg} \cdot \mathrm{kg}^{-1}\right)\end{array}$} \\
\hline 1 & 26.3 & 31.3 & 11.9 \\
\hline 2 & 56.6 & 11.5 & 20.3 \\
\hline 3 & 64.2 & 46.3 & 72.1 \\
\hline 4 & 109.4 & 42.2 & 38.5 \\
\hline 5 & 74.4 & 136.0 & 18.2 \\
\hline 6 & 55.3 & 131.8 & 23.8 \\
\hline 7 & 83.5 & 157.6 & 18.8 \\
\hline 8 & 92.6 & 153.2 & 16.5 \\
\hline \multicolumn{4}{|c|}{$\begin{array}{l}\text { Number of weeds per } 1 \mathrm{~m}^{2} \text { before rows closeness } \\
\text { Liczba chwastów na } 1 \mathrm{~m}^{2} \text { przed zwarciem rzędów }\end{array}$} \\
\hline 1 & 33.2 & 13.8 & 41.5 \\
\hline 2 & 16.7 & 14.2 & 85.0 \\
\hline 3 & 10.5 & 6.8 & 64.7 \\
\hline 4 & 5.8 & 4.7 & 81.0 \\
\hline 5 & 8.7 & 7.7 & 88.5 \\
\hline 6 & 9.8 & 4.6 & 46.9 \\
\hline 7 & 7.2 & 4.2 & 58.3 \\
\hline 8 & 5.0 & 2.5 & 50.0 \\
\hline \multicolumn{4}{|c|}{$\begin{array}{l}\text { Number of weeds per } 1 \mathrm{~m}^{2} \text { before tubers harvest } \\
\text { Liczba chwastów na } 1 \mathrm{~m}^{2} \text { przed zbiorem bulw }\end{array}$} \\
\hline 1 & 39.5 & 20.1 & 50.8 \\
\hline 2 & 23.9 & 17.6 & 73.6 \\
\hline 3 & 19.1 & 17.1 & 89.5 \\
\hline 4 & 10.8 & 13.0 & 120.3 \\
\hline 5 & 11.4 & 7.3 & 64.0 \\
\hline 6 & 13.2 & 6.7 & 50.7 \\
\hline 7 & 11.5 & 4.3 & 37.3 \\
\hline 8 & 7.4 & 4.3 & 58.1 \\
\hline
\end{tabular}


Barbaś, P., Sawicka, B. (2016). Impact of weeding methods on the content of nitrates in potato tubers. Nauka Przyr. Technol., 10, 4, \#49. DOI: http://dx.doi.org/10.17306/J.NPT.2016.4.49

Table 3 - cont. / Tabela 3 - cd.

\begin{tabular}{|c|c|c|c|}
\hline 1 & 2 & 3 & 4 \\
\hline \multicolumn{4}{|c|}{$\begin{array}{l}\text { Fresh matter of weeds before tubers harvest }\left(\mathrm{g} \cdot \mathrm{m}^{-2}\right) \\
\text { Świeża masa chwastów przed zbiorem bulw }\left(\mathrm{g} \cdot \mathrm{m}^{-2}\right)\end{array}$} \\
\hline 1 & 422.5 & 221.9 & 52.5 \\
\hline 2 & 321.1 & 145.9 & 45.4 \\
\hline 3 & 231.6 & 147.3 & 53.6 \\
\hline 4 & 111.3 & 81.8 & 73.4 \\
\hline 5 & 260.5 & 188.6 & 72.3 \\
\hline 6 & 227.4 & 141.2 & 62.0 \\
\hline 7 & 172.1 & 63.5 & 36.8 \\
\hline 8 & 161.0 & 114.0 & 70.8 \\
\hline \multicolumn{4}{|c|}{$\begin{array}{l}\text { Air-dry matter of weeds before tubers harvest }\left(\mathrm{g} \cdot \mathrm{m}^{-2}\right) \\
\text { Powietrznie sucha masa chwastów przed zbiorem bulw }\left(\mathrm{g} \cdot \mathrm{m}^{-2}\right)\end{array}$} \\
\hline 1 & 236.7 & 114.6 & 48.4 \\
\hline 2 & 142.7 & 56.2 & 39.3 \\
\hline 3 & 76.6 & 38.5 & 50.2 \\
\hline 4 & 55.8 & 48.7 & 87.2 \\
\hline 5 & 90.0 & 70.8 & 78.6 \\
\hline 6 & 94.4 & 59.9 & 63.4 \\
\hline 7 & 63.1 & 40.0 & 63.3 \\
\hline 8 & 62.8 & 49.0 & 78.0 \\
\hline
\end{tabular}

*As under Table 1.

*Jak pod tabelą 1 .

stability $(V=27.5 \%)$ among the assessed characteristics of the dependent variables, while the number of weeds at the pre-harvest time showed the highest variability $(\mathrm{V}=$ $68.0 \%$ ) (Table 3). The arithmetic mean, as well as standard deviation, influenced the value of the assessment coefficient. The nitrate content turned out to be the most changeable in the objects where infestation control was carried out with Sencor $70 \mathrm{WG}$ preparation at the dose of $1 \mathrm{~kg} \cdot \mathrm{ha}^{-1}$ at the potato pre-emergence time, while the most stable - in the control object.

The linear dependency for mechanical-chemical cultivation with a share of Sencor + Titus + Trend mixture applied at the potato pre-emergence time, where the determination coefficient practically equaled $100 \%$ (Table 4), was accepted as the most reliable, considering the dependencies between the nitrate content and the number of weeds in the rows pre-closeness period, in the range of standard deviation from the arithmetic mean. 
Barbaś, P., Sawicka, B. (2016). Impact of weeding methods on the content of nitrates in potato tubers. Nauka Przyr. Technol., 10, 4, \#49. DOI: http://dx.doi.org/10.17306/J.NPT.2016.4.49

Table 4. Relationship between nitrate content and indicators of potato infestation

Tabela 4. Zależność między zawartością azotanów a wskaźnikami zachwaszczenia ziemniaka

\begin{tabular}{|c|c|c|c|}
\hline $\begin{array}{l}\text { Weed control system* } \\
\text { Sposób pielęgnacji* }\end{array}$ & $\begin{array}{l}\text { Regression equation } \\
\text { Równanie regresji }\end{array}$ & $\begin{array}{l}\text { Significance level } \\
\text { Poziom istotności }\end{array}$ & $\begin{array}{c}\text { Determination coefficient } \\
\text { Współczynnik determinacji } \\
(\%)\end{array}$ \\
\hline 1 & 2 & 3 & 4 \\
\hline \multicolumn{4}{|c|}{$\begin{array}{l}\text { Number of weeds per } 1 \mathrm{~m}^{2} \text { before rows closeness } \\
\text { Liczba chwastów na } 1 \mathrm{~m}^{2} \text { przed zwarciem rzędów }\end{array}$} \\
\hline 1 & $y=-00.189 x+38.203$ & 0.000001 & 101.6 \\
\hline 2 & $y=1.8245 x-86.686$ & 0.000001 & 100.8 \\
\hline 3 & $y=0.0516 x+7.1881$ & 0.000001 & 100.0 \\
\hline 4 & $y=0.0145 x+4.2466$ & 0.000001 & 100.0 \\
\hline 5 & $y=0.0163 x+7.0624$ & 0.000002 & 100.0 \\
\hline 6 & $y=0.0015 x+9.7509$ & 0.000002 & 99.1 \\
\hline 7 & $y=0.0176 x+5.7408$ & 0.000003 & 100.0 \\
\hline 8 & $y=-0,013 x+6.2593$ & 0.000004 & 100.0 \\
\hline \multicolumn{4}{|c|}{$\begin{array}{l}\text { Number of weeds per } 1 \mathrm{~m}^{2} \text { before tubers harvest } \\
\text { Liczba chwastów na } 1 \mathrm{~m}^{2} \text { przed zbiorem bulw }\end{array}$} \\
\hline 1 & $\mathrm{y}=0.2294 \mathrm{x}+33.354$ & 0.0012 & 95.8 \\
\hline 2 & $y=1.8506 x-80.92$ & 0.0011 & 95.9 \\
\hline 3 & $y=0.1551 x+9.2694$ & 0.0010 & 95.3 \\
\hline 4 & $y=0.1438 x+4.8946$ & 0.0013 & 94.2 \\
\hline 5 & $y=0.032 x+9.0614$ & 0.0018 & 94.7 \\
\hline 6 & $y=0.0163 x+12.375$ & 0.0016 & 94.8 \\
\hline 7 & $\mathrm{y}=0.0147 \mathrm{x}+10.328$ & 0.0022 & 94.8 \\
\hline 8 & $y=-0.005 x+7.9637$ & 0.0031 & 94.2 \\
\hline \multicolumn{4}{|c|}{$\begin{array}{l}\text { Fresh matter of weeds before tubers harvest }\left(\mathrm{g} \cdot \mathrm{m}^{-2}\right) \\
\text { Świeża masa chwastów przed zbiorem bulw }\left(\mathrm{g} \cdot \mathrm{m}^{-2}\right)\end{array}$} \\
\hline 1 & $y=10.132 x+309.9$ & 0.000007 & 80.2 \\
\hline 2 & $y=16.022 x+586.79$ & 0.000006 & 79.9 \\
\hline 3 & $y=1.2933 x+148.67$ & 0.000007 & 80.4 \\
\hline 4 & $y=1.0636 x+4.9635$ & 0.000007 & 80.7 \\
\hline 5 & $y=-0.8546 x+324.11$ & 0.000135 & 81.3 \\
\hline 6 & $y=0.4038 x+205.15$ & 0.00027 & 81.6 \\
\hline 7 & $y=0.8055 x+75.198$ & 0.000414 & 82.0 \\
\hline 8 & $y=0.332 x+130.34$ & 0.000790 & 82.1 \\
\hline
\end{tabular}


Barbaś, P., Sawicka, B. (2016). Impact of weeding methods on the content of nitrates in potato tubers. Nauka Przyr. Technol., 10, 4, \#49. DOI: http://dx.doi.org/10.17306/J.NPT.2016.4.49

Table 4 - cont. / Tabela 4 - cd.

\begin{tabular}{|l|l|c|c|}
\hline 1 & 2 & 3 & 4 \\
\hline \multicolumn{4}{|c|}{ Air-dry matter of weeds before tubers harvest $\left(\mathrm{g} \cdot \mathrm{m}^{-2}\right)$} \\
Powietrznie sucha masa chwastów przed zbiorem bulw $\left(\mathrm{g} \cdot \mathrm{m}^{-2}\right)$ \\
\hline 1 & $\mathrm{y}=2.0929 \mathrm{x}+181.59$ & 0.001088 & 81.8 \\
2 & $\mathrm{y}=0.5606 \mathrm{x}+137.52$ & 0.000977 & 81.5 \\
3 & $\mathrm{y}=1.3559 \mathrm{x}+10.342$ & 0.001177 & 82.4 \\
4 & $\mathrm{y}=-0.1176 \mathrm{x}+68.71$ & 0.001045 & 82.9 \\
5 & $\mathrm{y}=0.2116 \mathrm{x}+74.374$ & 0.001684 & 83.7 \\
6 & $\mathrm{y}=0.0001 \mathrm{x}+94.493$ & 0.002705 & 84.0 \\
7 & $\mathrm{y}=0.3983 \mathrm{x}+29.862$ & 0.003685 & 84.7 \\
8 & $\mathrm{y}=0.4415 \mathrm{x}+21.94$ & 0.005326 & 85.1 \\
\hline
\end{tabular}

*As under Table 1.

*Jak pod tabelą 1 .

An increase in the number of weeds before the rows closeness influenced the increased accumulation of that form of nitrogen in tubers in all the methods of protection, apart from the extensive mechanical measures, carried out each second week, from planting till row closeness time. The coefficient of determination for the dependencies was over $99 \%$, which lets the authors consider the method to be highly reliable (Table 4). A significant increase in the content of nitrates was found in the tubers along with an increase of both the number and fresh and air-dry weed matter before the potato harvest. It is confirmed by high values of coefficients of determination $(>80 \%)$ of the considered equations (Table 4).

\section{Discussion}

In the carried out experiments, the accumulation of nitrates was dependent upon the cultivated potato cultivar. Mikos-Bielak et al. (1999), Zgórska (2003), Grudzińska and Zgórska (2008) report on an influence of the cultivated cultivar on the concentration of nitrates in potato tubers. Zgórska and Grudzińska (2009) proved that mean content of nitrates in very early and early cultivar tubers was 224 and $205 \mathrm{mg} \mathrm{NO} 3$ per $1 \mathrm{~kg}$ of fresh matter, respectively, while it was 2-fold lower in the medium early cultivars, and it did not exceed $50 \mathrm{mg} \mathrm{NO} 3$ per $1 \mathrm{~kg}$ of fresh matter in medium late cultivars. Nitrogen (V) content in Wójcik-Stopczyńska et al. (2012) research was found within the range 31.4-233.3 mg NO $\mathrm{NO}_{3}$ per $1 \mathrm{~kg}$, but only in three of the 25 examined samples their content exceeded $200 \mathrm{mg} \mathrm{NO} 3$ per $1 \mathrm{~kg}$, and in 11 it was lower than $100 \mathrm{mg} \mathrm{NO} \mathrm{N}_{3}$ per $1 \mathrm{~kg}$. The varied nitrogen content in the investigated cultivars tubers was also observed by Zarzyńska and Wroniak (2007) but the content was dependent upon the type of soil, place of cultivation and farming system. For example, the 'Bartek' cultivar showed an insignificant accumulation of the component in its tubers independently of the cultiv- 
Barbaś, P., Sawicka, B. (2016). Impact of weeding methods on the content of nitrates in potato tubers. Nauka Przyr. Technol., 10, 4, \#49. DOI: http://dx.doi.org/10.17306/J.NPT.2016.4.49

ation place, on the other hand, the 'Korona' cultivar tubers showed the undesirable compounds content to be generally high, and while cultivated on heavy soils the level exceeded 2-fold the norm defined as safe, i.e. $250 \mathrm{mg} \mathrm{NaNO}$ per $1 \mathrm{~kg}$. The medium late cultivars tubers showed an insignificantly varied content of nitrates in relation to the place of cultivation, whereas meaningful in case of both very early and early cultivars. The carried out chemical analysis of the investigated potato bulbs proved a significant increase of nitrates accumulation as a result of the applied herbicides. Boligłowa et al. (2004) also proved a significant increase in the nitrate content in potato tubers, depending upon the introduced herbicide active substance.

An increase in the nitrate content was observed after a mixture of linuron + pendimetalina was applied. The plants treated with cyanosis, linuron, linuron combined with cyanosis, as well as metribuzin, produced less nitrates in the bulbs, compared to the control object. Wichrowska (2007), investigating the influence of herbicides (Afalon $50 \mathrm{WP}$, Azogard $50 \mathrm{WP}$, Sencor $70 \mathrm{WG}+$ adjuvant Olbras $88 \mathrm{EC}$, Apyros $75 \mathrm{WG}+$ adjuvant Atpolan $80 \mathrm{EC}$ ) on the degree of harmful nitrates (V) accumulation in potato tubers after harvest, showed a significant increase in the content of the form of nitrogen, compared to the control object. The highest increase of the nitrates level (V) was reported by the author after an application of Sencor $70 \mathrm{WG}+$ adjuvant Olbras 88 EC. Pszczółkowski and Sawicka's (2009) studies proved that the highest, negative influence on the nitrate content in tubers of the early potato cultivars was caused by herbicide Afalon application and simultaneously Command + Afalon herbicide mixture.

The carried out tests proved that permissible nitrates (V) content in tubers after an application of herbicides (on average $70.2 \mathrm{mg} \mathrm{N}-\mathrm{NO}_{3}$ per $1 \mathrm{~kg}$ of fresh matter) was not exceeded. The content of this form of nitrogen should not exceed $200 \mathrm{mg} \cdot \mathrm{kg}^{-1}$ of fresh matter, in agreement with the Ordinance of the Minister of Health of January 13, 2003 (Rozporządzenie..., 2003).

The research proved that the nitrate content in potato tubers turned out to be dependent also on the meteorological conditions at the vegetation period. It was observed that the applied chemical weed control method on a potato plantation, with Sencor $70 \mathrm{WG}+$ Fusilade Forte 150 EC preparations mixture, as well as Sencor $70 \mathrm{WG}+$ Titus $25 \mathrm{WG}+$ Trend 90 EC herbicides and adjuvant mixture - at the post-emergence period - brought about a danger of a higher nitrates accumulation.

Similar observations were presented by Frydecka-Mazurczyk and Zgórska (2000). They proved that a temporary deficit of rainfall and high temperature, as well as excessive rainfall and low temperature during the vegetation season, cause the compounds increase in potato tubers. A high dependency of the nitrate content on the environmental conditions, in the aspect of various weed control methods, may be connected with an excessive moisture or soil drought at the vegetation period. The importance of moisture conditions and their influence on the concentration of nitrates in tubers are also paid attention to in the research of Wierzbicka (2011). The results of the research indicate that the tubers irrigated at the drought time, contained a lower amount of the compounds compared to those cultivated without irrigation. The conducted equations of regression between the elements of weed infestation of a plantation and the content of nitrates in potatoes proved that limiting weed infestation of a plant stand, both at the pre- and post-emergence period, brought about a reduction in the accumulation of nitrates in potato tubers. Różyło and Pałys (2009) while investigating the values found no interdependen- 
Barbaś, P., Sawicka, B. (2016). Impact of weeding methods on the content of nitrates in potato tubers. Nauka Przyr. Technol., 10, 4, \#49. DOI: http://dx.doi.org/10.17306/J.NPT.2016.4.49

cies between the weed infestation elements and the nitrogen content in potato tubers. The authors proved that only air-dry weed-matter was decisive, to the most meaningful degree, in cumulating ash components in potato tubers.

\section{Conclusions}

1. Weed control methods had a decisive impact on the content of nitrates in potato tubers. The highest concentration of nitrates showed the tubers coming from the object where at the pre-emergence period Sencor $70 \mathrm{WG}\left(1 \mathrm{~kg} \cdot \mathrm{ha}^{-1}\right)+$ Titus $25 \mathrm{WG}\left(40 \mathrm{~g} \cdot \mathrm{ha}^{-1}\right)$ + Trend 90 EC $(0.1 \%)$ preparations mixture was used.

2. Post-emergence period application of a decreased dose of Sencor $70 \mathrm{WG}(0.3$ $\left.\mathrm{kg} \cdot \mathrm{ha}^{-1}\right)$ preparation combined with an application of Titus $25 \mathrm{WG}\left(30 \mathrm{~g} \cdot \mathrm{ha}^{-1}\right)$ preparation and adjuvant Trend $90 \mathrm{EC}(0.1 \%)$ is the least dangerous option, as far as accumulation of nitrates in tubers is concerned.

3. The impact of weed control method on the content of nitrates depended on the weather conditions at the period of the experiment. Application of the chemical method on a potato plantation with Sencor $70 \mathrm{WG}+$ Fusilade Forte $150 \mathrm{EC}$ and Sencor $70 \mathrm{WG}$ + Titus $25 \mathrm{WG}+$ Trend 90 EC preparations - at the post-emergence period, causes a higher accumulation of nitrates in potato tubers in dry years.

4. The studied changes showed a variability of accumulation of the form of nitrogen in tubers. The medium early cultivar 'Irga' cumulated more nitrates in tubers than the medium late 'Fianna'.

5. Reducing weed infestation of the plantation, both before and after potato planting, as well as after potato emergence, brought about a decrease in the accumulation of nitrates in potato tubers.

\section{References}

Boligłowa, E., Gleń, K., Pisulewski, P. (2004). Wpływ stosowania herbicydów na plonowanie i niektóre cechy jakości bulw ziemniaka. Zesz. Probl. Post. Nauk Roln., 500, 391-397.

Cieślik, E. (1995). Zawartość związków azotowych w bulwach ziemniaka w aspekcie żywieniowym i toksykologicznym. Zesz. Nauk. AR Krak. Rozpr., 203.

Dżugan, M., Pasternakiewicz, A. (2007). Ocena dziennego pobrania azotanów z wyrobami mięsnymi i woda pitną. Proc. ECOpole, 1, 1/2, 129-132.

Fortuna, T. (2003). Podstawy analizy żywności. Kraków: Wyd. AR w Krakowie.

Friedman, M. (2006). Potato glicoalkaloids and metabolites: roles in the plant and in the diet. J. Agric. Food Chem., 54, 23, 8655-8681.

Frydecka-Mazurczyk, A., Zgórska, K. (2000). Zawartość azotanów (V) w bulwach ziemniaka w zależności od odmiany, miejsca uprawy i terminu zbioru. Żywn. Nauka Technol. Jakość Supl., 7, 4, 46-52.

Grudzińska, M., Zgórska, K. (2008). Wpływ warunków meteorologicznych na zawartość azotanów(V) w bulwach ziemniaka. Żywn. Nauka Technol. Jakość, 60, 5, 98-106.

Haddad, H., Bani-Hani, N. M., Al-Tabbal, J. A., Al-Fraihat, A. H. (2016). Effect of different potassium nitrate levels on yield and quality of potato tubers. J. Food Agric. Environ., 14, 1, 101-107. [www.world-food.net]. 
Barbaś, P., Sawicka, B. (2016). Impact of weeding methods on the content of nitrates in potato tubers. Nauka Przyr. Technol., 10, 4, \#49. DOI: http://dx.doi.org/10.17306/J.NPT.2016.4.49

Janowiak, J., Spychaj-Fabisiak, E., Wszelaczyńska, E., Pińska, M., Murawska, B. (2009). Effect of many-year natural and mineral fertilization on yielding and the content of nitrates (V) in potato tubers. J. Cent. Eur. Agric., 10, 1, 109-113.

Kardasz, M., Pawłowska, D. (2008). Rola składników odżywczych oraz innych substancji w powstawaniu nowotworów. Nowa Med., 2, 7-14.

Knuthsen, P., Jensen, U., Schmidt, B., Larsen, I. K. (2009). Glycoalkaloids in potatoes: content of glycoalkaloids in potatoes for consumption. J. Food Compos. Anal., 22, 6, 577-581.

Koronacki, J., Mielniczuk, J. (2006). Statystyka dla studentów kierunków technicznych i przyrodniczych. Warszawa: WNT.

Kościańska, B., Rodecka-Gustaw, E. (2011). Nawozy sztuczne, azotyny, a nowotwory złośliwe. Med. Og. Nauki Zdr., 17, 1, 33-38.

Leszczyński, W. (2012). Żywieniowa wartość ziemniaka i przetworów ziemniaczanych. (Przegląd literatury). Biul. Inst. Hod. Aklim. Rośl., 266, 5-20.

Marks, N. (2009). Zawartość azotanów, azotynów i metali ciężkich w bulwach ziemniaka w zależności od długości okresu przechowywania. Inż. Roln., 13, 110, 1, 183-187.

Mikos-Bielak, M., Sawicka, B., Rudzińska, B. (1999). Azotany i azotyny w bulwach wczesnych odmian ziemniaka. Biul. Inst. Hod. Aklim. Rośl., 209, 137-147.

Mozolewski, W., Smoczyński, S. (2004). Effect of culinary processes on the content of nitrates and nitrites in potato. Pak. J. Nutr., 3, 6, 357-361.

Murawa, D., Banaszkiewicz, T., Majewska, E., Błaszczuk, B., Sulima, J. (2008). Zawartość azotanów(III) i (V) w wybranych gatunkach warzyw i ziemniakach dostępnych w handlu w Olsztynie w latach 2003-2004. Bromatol. Chem. Toksykol., 41, 1, 67-71.

Pszczółkowski, P., Sawicka, B. (2009). Zawartość białka i azotanów w bulwach bardzo wczesnych odmian ziemniaka uprawianych pod osłonami. Zesz. Probl. Post. Nauk Roln., 542, 413-426.

Rozporządzenie Ministra Zdrowia z dnia 13 stycznia 2003 r. w sprawie maksymalnych poziomów zanieczyszczeń chemicznych i biologicznych, które mogą znajdować się w żywności, składnikach żywności, dozwolonych substancjach dodatkowych, substancjach pomagających w przetwarzaniu albo na powierzchni żywności. (2003). Dz. U., 37, item 326.

Różyło, K., Pałys, E. (2009). Skład chemiczny bulw ziemniaka i jego korelacje z zachwaszczeniem w zależności od rodzaju nawożenia oraz kategorii agronomicznej gleby. Ann. Univ. Mariae Curie-Skłodowska Sect. E, 64, 3, 110-119.

Rytel, E. (2010). Wybrane substancje odżywcze i antyżywieniowe ziemniaka i zmiany ich zawartości podczas przetwarzania na produkty spożywcze. Zesz. Probl. Post. Nauk Roln., 557, 43-61.

Rytel, E. (2012). Changes in the levels of glycoalkaloids and nitrates after the dehydration of cooked potatoes. Am. J. Pot. Res., 89, 6, 501-507.

Tajner-Czopek, A., Jarych-Szyszka, M., Lisińska, G. (2008). Changes in glycoalkaloids contents of potatoes destined for consumption. Food Chem., 106, 706-711.

Trętowski, J., Wójcik, A. R. (1991). Metodyka doświadczeń rolniczych. Siedlce: Wyd. WSRP.

Valdés-Ramos, R., Benítez-Arciniega, A. D. (2007). Nutrition and immunity in cancer. Br. J. Nutr., 98, 1, 127-132.

Wichrowska, D. (2007). The content of nitrate(V) in potato tubers storage in temperature $4^{\circ} \mathrm{C}$. Pol. J. Nat. Sci. Suppl., 4, 121-127.

Wichrowska, D., Wojdyła, T. (2011). Wpływ herbicydów na zmiany zawartości azotanów (V) w bulwach ziemniaka po zbiorach i przechowywaniu. Zesz. Nauk. UE Pozn., 206, 27-36.

Wierzbicka, A. (2011). Some quality characteristics of potato tubers grown in the ecological system depending on irrigation. J. Res. Appl. Agric. Eng., 56, 4, 203-207.

Wójcik-Stopczyńska, B., Grzeszczuk, M., Jakubowska, B. (2012). Zawartość niektórych składników odżywczych i potencjalnie szkodliwych w ziemniakach jadalnych pochodzących z sieci handlowej. Rocz. PZH, 63, 2, 207-212.

Zarzecka, K., Gugała, M., Sikorska, A. (2015). The effect of herbicides on the content of glycoalkaloids in the leaves and tubers of potato. Plant Soil Environ., 61, 7, 328-331. doi: 10.17221/ 314/2015-PSE 
Barbaś, P., Sawicka, B. (2016). Impact of weeding methods on the content of nitrates in potato tubers. Nauka Przyr. Technol., 10, 4, \#49. DOI: http://dx.doi.org/10.17306/J.NPT.2016.4.49

Zarzyńska, K., Wroniak, J. (2007). Różnice w jakości plonu bulw ziemniaków uprawianych w systemie ekologicznym w zależności od niektórych czynników agrotechnicznych. J. Res. Appl. Agric. Eng., 52, 4, 108-114.

Zgórska, K. (2003). Zawartość azotanów w bulwach wybranych odmian jadalnych. Ziemn. Pol., $4,14-17$.

Zgórska, K., Grudzińska, M. (2009). Rozmieszczenie azotanów(V) w różnych częściach wybranych warzyw i w bulwach ziemniaka. Biul. Nauk. UWM Olszt., 30, 103-108.

\title{
ODDZIALYWANIE METOD PIELĘGNACJI NA ZAWARTOŚĆ AZOTANÓW W BULWACH ZIEMNIAKA
}

\begin{abstract}
Streszczenie
Wyniki badań oparto na doświadczeniu polowym wykonanym w latach 2007-2009 w zakładzie doświadczalnym Instytutu Hodowli i Aklimatyzacji Roślin - Państwowego Instytutu Badawczego w Jadwisinie na glebie płowej, o składzie granulometrycznym piasku gliniastego. Eksperyment założono metodą losowanych podbloków w układzie zależnym, split-plot, w trzech powtórzeniach. Czynnikiem I rzędu były odmiany ziemniaka: 'Irga' i 'Fianna', czynnik II rzędu stanowiły sposoby regulacji zachwaszczenia: 1) obiekt kontrolny - bez chemicznej ochrony, 2) ekstensywne zabiegi mechaniczne (co 2 tygodnie) od posadzenia aż do zwarcia rzędów, 3) Sencor 70 WG $1 \mathrm{~kg} \cdot \mathrm{ha}^{-1}$ przed wschodami ziemniaka, 4) Sencor $70 \mathrm{WG}-1 \mathrm{~kg} \cdot \mathrm{ha}^{-1}+$ Titus $25 \mathrm{WG}-40 \mathrm{~g} \cdot \mathrm{ha}^{-1}+$ Trend $90 \mathrm{EC}-0,1 \%$ przed wschodami ziemniaka, 5) Sencor $70 \mathrm{WG}-0,5 \mathrm{~kg} \cdot \mathrm{ha}^{-1}$ po wschodach ziemniaka, 6) Sencor $70 \mathrm{WG}-0,3 \mathrm{~kg} \cdot \mathrm{ha}^{-1}+$ Titus $25 \mathrm{WG}-30 \mathrm{~g} \cdot \mathrm{ha}^{-1}+$ Trend $90 \mathrm{EC}-0,1 \%$ po wschodach ziemniaka, 7) Sencor $70 \mathrm{WG}-0,3 \mathrm{~kg} \cdot \mathrm{ha}^{-1}+$ Fusilade Forte $150 \mathrm{EC}-2 \mathrm{dm} \cdot \mathrm{ha}^{-1}$ po wschodach ziemniaka, 8) Sencor $70 \mathrm{WG}-0,3 \mathrm{~kg} \cdot \mathrm{ha}^{-1}+$ Apyros $75 \mathrm{WG}-26,5 \mathrm{~g} \cdot \mathrm{ha}^{-1}+$ Atpolan $80 \mathrm{SC}-1 \mathrm{dm} \cdot \mathrm{ha}^{-1}$ po wschodach ziemniaka. Bulwy zebrano w fazie dojrzałości technicznej ziemniaka. Zawartość azotanów oznaczono metodą kolorymetryczną. Czynnik genetyczny decydował w dużej mierze o wartości tej cechy. Większą zawartością azotanów charakteryzowała się średniowczesna odmiana 'Irga', a mniejszą - średniopóźna odmiana 'Fianna'. Koncentracja azotanów w bulwach ziemniaka zależała od metod pielęgnacji oraz warunków atmosferycznych w latach badań. Największą koncentracją azotanów odznaczały się bulwy pochodzące z obiektu, gdzie przed wschodami ziemniaka użyto preparatów: Sencor $70 \mathrm{WG}+$ Titus $25 \mathrm{WG}+$ Trend 90 EC.
\end{abstract}

Słowa kluczowe: ziemniak, odmiana, metody pielęgnowania, azotany

Corresponding address - Adres do korespondencji:

Piotr Barbaś, Zakład Agronomii Ziemniaka, Instytut Hodowli i Aklimatyzacji Roślin - Państwowy Instytut Badawczy, Oddziat Jadwisin, ul. Szaniawskiego 15, 05-140 Serock, Poland, e-mail: p.barbas@ihar.edu.pl

Accepted for publication - Zaakceptowano do opublikowania:

6.12.2016

For citation - Do cytowania:

Barbaś, P., Sawicka, B. (2016). Impact of weeding methods on the content of nitrates in potato tubers. Nauka Przyr. Technol., 10, 4, \#49. DOI: http://dx.doi.org/10.17306/J.NPT.2016.4.49 